\title{
PERAN PENGELOMPOKAN MOLEKUL PADA HYDROUS ETANOL TERHADAP KINERJA MESIN
}

\author{
I Made Suarta1), I Putu Gede Sopan Rahtika ${ }^{2)}$, Putu Wijaya Sunu ${ }^{3)}$ Ketut Bangse $^{4)}$, I Nengah ${ }^{5)}$ \\ Darma Susila $^{5}$ \\ ${ }^{1}$ Teknik Mesin, Politeknik Negeri Bali, Bukit Jimbaran, Badung 80351 \\ ${ }^{2}$ Teknik Mesin, Politeknik Negeri Bali, Bukit Jimbaran, Badung 80351 \\ ${ }^{3}$ Teknik Mesin, Politeknik Negeri Bali, Bukit Jimbaran, Badung 80351 \\ ${ }^{4}$ Teknik Mesin, Politeknik Negeri Bali, Bukit Jimbaran, Badung 80351 \\ ${ }^{5}$ Teknik Mesin, Politeknik Negeri Bali, Bukit Jimbaran, Badung 80351 \\ E-mail: suarta@pnb.ac.id
}

\begin{abstract}
In this study observed the role of molecular clustering on engine performance produced by hydrous ethanol fuel $(95.5 \%$ v). The test was performed using variation load for four-cylinder motor. Engine performance is measured using Brake Power Engine load cell type indicator TD 800PM. The engine performance produced by anhydrous ethanol was also tested. The resulting engine performance of both fuels is compared. The results showed that the power produced by hydrous ethanol was slightly higher than that of anhydrous ethanol. The charging effisiency generated by hydrous ethanol is upper than that of anhydrous ethanol.
\end{abstract}

Keywords: anhydrous ethanol; fuel; ethanol; hydrous ethanol; engine performance

\begin{abstract}
Abstrak
Pada penelitian ini diamati peran pengelompokan molekul terhadap kinerja mesin yang dihasilkan bahan bakar hydrous etanol $(95,5 \% \mathrm{v})$. Pengujian dilakukan menggunakan pembebanan bervariasi pada motor bakar satu silinder empat langkah. Kinerja mesin diukur menggunakan Engine Brake Power indikator load cell tipe TD 800PM. Kinerja mesin yang dihasilkan oleh anhydrous etanol juga diuji. Kinerja mesin yang dihasilkan kedua bahan bakar tersebut dibandingkan. Hasil penelitian menunjukkan Daya mesin yang dihasilkan hydrous etanol sedikit lebih tinggi dari anhydrous etanol. effisiensi pengisian yang dihasilkan oleh hydrous etanol lebih tinggi dari anhydrous etanol.
\end{abstract}

Kata Kunci: anhydrous etanol; bahan bakar; etanol; hydrous etanol; kinerja mesin

\section{PENDAHULUAN}

Keamanan energi dan pemanasan global menjadi alasan utama dalam penggunaan energi alternatif dimasa depan yang tidak dapat dielakkan (Omar dkk,2018; Suarta dkk,2017). Etanol adalah salah satu energi alternatif yang bersifat renewable yang dapat digunakan secara langsung hampir pada semua mesin pembakaran menggunakan busi(Chuepeng dkk,2016). Penggunaan etanol membutuhkan energi yang sangat tinggi dalam pemurniannya (Suarta dkk,2016; Fagundez dkk,2016). Salah satu cara untuk mengurangi biaya produksi etanol sebagai bahan bakar adalah menggunakannya dengan sedikit kadar air(Lanzanova dkk,2016). Disamping membutuhkan biaya yang lebih rendah dalah proses produksinya, kecepatan pembakaran pembakaran dan batas mampu nyala (ER) dari azeotrope etanol juga lebih baik dari anhydrous etanol (Suarta dkk,2016; Breaux dan Acharya,2013).

Pemanfaatan biofuel dari kelompok alkohol memainkan peran penting untuk mengurangi Emisi gas buang yang berbahaya. Karena itu, peneliti di seluruh dunia selama beberapa dekade terakhir sudah mulai meneliti pengaruh alkohol terhadap kinerja dan emisi gas buang dalam motor bensin. Memang benar bahwa performa mesin dan emisi gas buang pada motor bakar dipengaruhi oleh beberapa faktor. Perbedaan dalam properti dari bahan bakar alkohol menyebabkan variasi sifat dari kinerja dan emisi mesin bensin maupun diesel (Suarta dkk,2017; Yusri dkk 2017). 
Morganti dkk(2018); Schifter dkk(2013); Suarta dkk(2016). Etanol adalah salah satu bahan bakar yang paling diminati untuk mesin bensin. Sehingga etanol banyak digunakan sebagai oktan enhancer maupun diblending dengan bahan bakar lain. Etanol menawarkan bahan bakar kualitas oktan tinggi dan panas penguapan empat kali lebih besar dari pada bensin secara stoikiometri. Data ini kemudian digunakan untuk membandingkan peta konsumsi bahan bakar untuk mensimulasikan kebutuhan bahan bakar kendaraan.
Pengujian emisi dan performance generator set dengan menggunakan bahan bakar etanol dilakukan oleh (Suarta dkk,2017; Munsin dkk2013). Munsin dkk (2013) menyimpulkan bahwa etanol dengan kadar air 5\% pada putaran mesin konstan $3600 \mathrm{rpm}$ campuran stoichiometri emisinya sangat rendah. Grafik hasil penelitiannya dapat dilihat pada Gambar 1 .

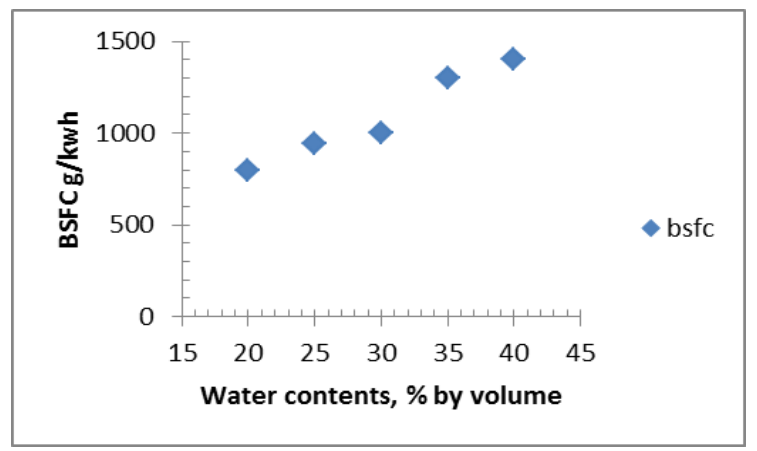

Gambar 1. Hubungan kadar air terhadap kebutuhan bahan bakar. Sumber: R. Munsin. 2013

Hasil percobaan (Munsin dkk,2013) telah menemukan bahwa mesin mengkonsumsi etanol hidrous lebih besar sebesar $10 \%$ secara umum dibandingkan dengan etanol anhidrat pada campuran kurus equivalen ratio 0,67 .

Penelitian saat ini bertujuan membandingkan kinerja mesin menggunakan bahan bakar hydrous etanol (azeotropik) dengan bahan bakar anhydrous etanol. Pengujian dilakukan menggunakan beban bervariasi pada kedua jenis bahan bakar tersebut.

\section{METODE PENELITIAN}

Penelitian dilakukan dengan metode pengujian dengan peralatan uji laboratorium. Langkah awal pada penelitian dilakukan dilaboratorium analitik. Anhydrous etanol yang digunakan adalah absolute ethanol for analisys dari Merck, selanjutnya diencerkan menjadi etanol hydrous pada kadar air $(95,5 \% \mathrm{v})$. Selanjutnya pengujian eksperimental (experimental research), yaitu melakukan pengujian terhadap kinerja mesin menggunakan dinamo meter.

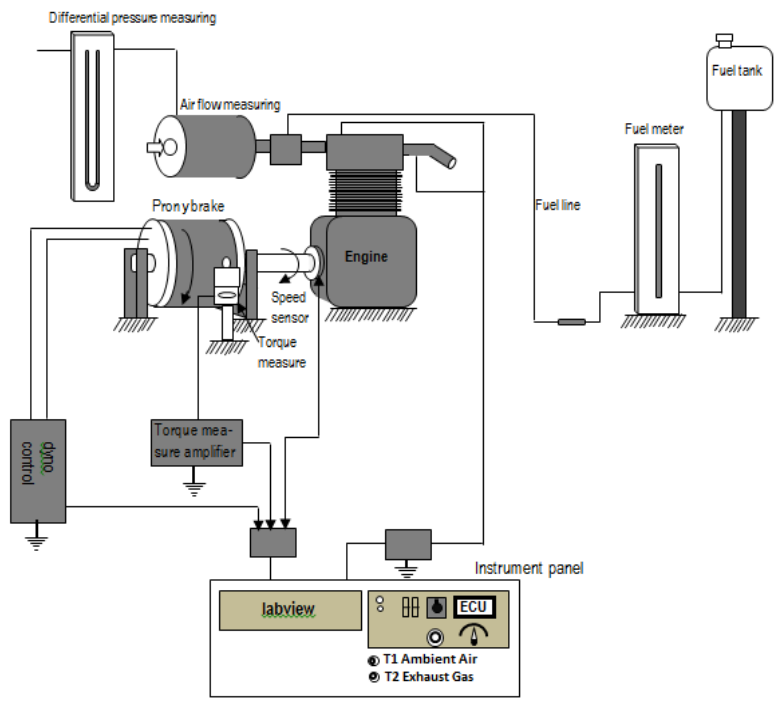

Gambar 2. Set-up pengujian

HASIL DAN PEMBAHASAN

24 | Jurnal Integrasi | Vol.11 No.1, April 2019, 23-27 |e-ISSN: 2548-9828
Dengan menggunakan data awal putaran mesin $3500 \mathrm{rpm}$, beban meningkat tiap $1 \mathrm{~kg}$. Panjang 
lengan beban $20 \mathrm{~cm}$, Dengan penggunakan formula (Torsi) $\tau=$ Fr, Konsumsi bahan bakar $\mathrm{Q}_{\mathrm{mf}}(\mathrm{kg} / \mathrm{s})$ didapat dari persamaan $Q_{\mathrm{mf}}=Q_{\mathrm{vf}}, \rho_{\mathrm{f}}$, Daya yang dihasilkan $(P)=\frac{2 \pi F r n}{60}$ dalam $\mathrm{kW}$. Laju aliran udara melalui plat orifice dihitung dengan persamaan $\mathrm{Q}_{\mathrm{va}}=\frac{\mathrm{Q}_{\mathrm{ma}}}{\mathrm{P}_{\mathrm{a}}}=\alpha \varepsilon \frac{\pi \mathrm{d}^{2}}{4} \sqrt{\frac{2 \Delta \mathrm{p}}{\rho_{\mathrm{a}}}}, \quad$ Volume ruang bakar
$Q_{\text {th }}=$ engine total displacement volume $x \frac{n}{2 x 60}\left(\frac{m^{\mathrm{s}}}{\mathrm{s}}\right)$, effisiensi volumetrik $\eta_{v}=\frac{Q_{v a}}{Q_{t h z}} \times 100 \%$

Sehingga didapat hasil perhitungan seperti yang disajikan dalam tabel 1 dan 2

Tabel 1. Hasil perhitungan data etanol murni TD 800PM SINGLE-CYLINDER ENGINE TEST-BED, Mechanical Absorber

Room temperatur : 29 Atmospheric pressure : $105,2 \mathrm{kPa}$ Opening position of throttle valve : -

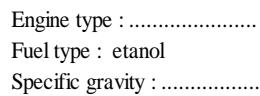

Tested by :................... Date : 5/7/2018

Air box / Orifice diameter : 300/15

Manometer slope : $1: 5$

Manometer reading for zero air flow :

\begin{tabular}{|c|c|c|c|c|c|c|c|c|c|c|c|c|c|c|c|c|c|c|}
\hline \multirow{4}{*}{$\begin{array}{c}\mathrm{n} \\
(\mathrm{rpm})\end{array}$} & \multirow{4}{*}{$\begin{array}{c}\text { Net } \\
\text { Force } \\
(\mathrm{kg})\end{array}$} & \multirow{4}{*}{$\begin{array}{c}\tau \\
(\mathrm{N} . \mathrm{m})\end{array}$} & \multicolumn{5}{|c|}{ Fuel Consumtion } & \multicolumn{6}{|c|}{ Air flow rate } & \multirow{4}{*}{$\begin{array}{l}\mathrm{A} / \mathrm{F} \\
\text { ratio }\end{array}$} & \multicolumn{2}{|c|}{ Temperatur $\left({ }^{\circ} \mathrm{C}\right)$} & \multirow{4}{*}{$\begin{array}{c}\mathrm{P} \\
(\mathrm{kW})\end{array}$} & \multirow{4}{*}{$\begin{array}{c}\eta_{\mathrm{v}} \\
(\%)\end{array}$} \\
\hline & & & \multicolumn{3}{|c|}{ Graduated cylinder } & \multirow{3}{*}{$\begin{array}{c}\text { Indicator } \\
\mathrm{Q}_{\mathrm{f}} \\
(\mathrm{kW})\end{array}$} & \multirow{3}{*}{$\begin{array}{r}\mathrm{Q}_{\mathrm{mf}} \\
(\mathrm{kg} / \mathrm{s})\end{array}$} & \multicolumn{4}{|c|}{ Air box } & \multirow{3}{*}{$\begin{array}{c}\text { Indicator } \\
\mathrm{Q}_{\mathrm{va}} \\
\left(\mathrm{m}^{3} / \mathrm{s}\right)\end{array}$} & \multirow{3}{*}{$\begin{array}{c}\mathrm{Q}_{\mathrm{ma}} \\
(\mathrm{kg} / \mathrm{s})\end{array}$} & & \multirow{3}{*}{$\begin{array}{c}\text { Engine } \\
\text { Inlet air } \\
\text { (T1) }\end{array}$} & \multirow{3}{*}{$\begin{array}{c}\text { Exhaust } \\
\text { gas } \\
\text { (T2) }\end{array}$} & & \\
\hline & & & Volume & Time & $Q_{v f}$ & & & \multicolumn{3}{|c|}{$\begin{array}{c}\text { Manometer } \\
\text { Reading } \mathrm{mm} \mathrm{H} 2 \mathrm{O} \\
\end{array}$} & \multirow{2}{*}{$\begin{array}{c}\mathrm{Q}_{\mathrm{th}} \\
\left(\mathrm{m}^{3} / \mathrm{s}\right)\end{array}$} & & & & & & & \\
\hline & & & & & & & & Left & Right & Net & & & & & & & & \\
\hline 3500 & 0 & 0 & 5 & 17.62 & 0.00028 & 5.96311 & 0.0002242 & 285 & 115 & 170 & 0.0057 & 0.00161 & 0.0019 & 8.4004 & 28 & 281 & 0 & 28.155 \\
\hline 3136 & 1 & 1.96 & 5 & 18.01 & 0.00028 & 5.83398 & 0.0002193 & 285 & 115 & 170 & 0.0051 & 0.00161 & 0.0019 & 8.5863 & 28 & 300 & 0.6443 & 31.424 \\
\hline 3100 & 2 & 3.92 & 5 & 19.11 & 0.00026 & 5.49817 & 0.0002067 & 285 & 115 & 170 & 0.0051 & 0.00161 & 0.0019 & 9.1108 & 28 & 281 & 1.2739 & 31.788 \\
\hline 3000 & 3 & 5.88 & 5 & 19.45 & 0.00026 & 5.40206 & 0.0002031 & 280 & 120 & 160 & 0.0049 & 0.001561 & 0.0018 & 8.996 & 28 & 282 & 1.8491 & 31.867 \\
\hline 2600 & 4 & 7.84 & 5 & 20.15 & 0.00025 & 5.21439 & 0.000196 & 270 & 130 & 140 & 0.0042 & 0.001461 & 0.0017 & 8.7178 & 28 & 261 & 2.1368 & 34.395 \\
\hline 2313 & 5 & 9.8 & 5 & 21.18 & 0.00024 & 4.96081 & 0.0001865 & 270 & 130 & 140 & 0.0038 & 0.001461 & 0.0017 & 9.1635 & 28 & 247 & 2.3761 & 38.663 \\
\hline
\end{tabular}

Tabel 2. Hasil perhitungan data etanol 95,5\% TD 800PM SINGLE-CYLINDER ENGINE TEST-BED, Mechanical Absorber

Room temperatur : 29 Atmospheric pressure : 105,2 $\mathrm{kPa}$ Opening position of throttle valve : -

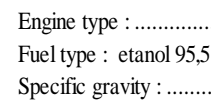

Tested by :.................. Date : 5/7/2018

Air box / Orifice diameter : $300 / 15$

Manometer slope : $1: 5$

Manometer reading for zero air flow :

\begin{tabular}{|c|c|c|c|c|c|c|c|c|c|c|c|c|c|c|c|c|c|c|}
\hline \multirow{4}{*}{$\begin{array}{c}\mathrm{n} \\
(\mathrm{rpm})\end{array}$} & \multirow{4}{*}{$\begin{array}{l}\text { Net } \\
\text { Force } \\
(\mathrm{kg})\end{array}$} & \multirow{4}{*}{$\begin{array}{c}\tau \\
(\mathrm{N} . \mathrm{m})\end{array}$} & \multicolumn{5}{|c|}{ Fuel Consumtion } & \multicolumn{6}{|c|}{ Air flow rate } & \multirow{4}{*}{$\begin{array}{l}\mathrm{A} / \mathrm{F} \\
\text { ratio }\end{array}$} & \multicolumn{2}{|c|}{ Temperatur $\left({ }^{\circ} \mathrm{C}\right)$} & \multirow{4}{*}{$\begin{array}{c}\mathrm{P} \\
(\mathrm{kW})\end{array}$} & \multirow{4}{*}{$\begin{array}{c}\eta_{\mathrm{v}} \\
(\%)\end{array}$} \\
\hline & & & \multicolumn{3}{|c|}{ Graduated cylinder } & \multirow{3}{*}{$\begin{array}{c}\text { Indicator } \\
\mathrm{Q}_{\mathrm{f}} \\
(\mathrm{kW})\end{array}$} & \multirow{3}{*}{$\begin{array}{r}\mathrm{Q}_{\mathrm{mf}} \\
(\mathrm{kg} / \mathrm{s})\end{array}$} & \multicolumn{4}{|c|}{ Air box } & \multirow{3}{*}{$\begin{array}{c}\text { Indicator } \\
\mathrm{Q}_{\mathrm{va}} \\
\left(\mathrm{m}^{3} / \mathrm{s}\right)\end{array}$} & \multirow{3}{*}{$\begin{array}{r}\mathrm{Q}_{\mathrm{ma}} \\
(\mathrm{kg} / \mathrm{s})\end{array}$} & & \multirow{3}{*}{$\begin{array}{c}\text { Engine } \\
\text { Inlet air } \\
\text { (T1) }\end{array}$} & \multirow{3}{*}{$\begin{array}{c}\text { Exhaust } \\
\text { gas } \\
\text { (T2) }\end{array}$} & & \\
\hline & & & \multirow{2}{*}{$\begin{array}{c}\text { Volume } \\
(\mathrm{ml})\end{array}$} & \multirow{2}{*}{$\begin{array}{l}\text { Time } \\
\text { (s) }\end{array}$} & \multirow{2}{*}{$\begin{array}{l}\mathrm{Q}_{\mathrm{vf}} \\
(1 / \mathrm{s})\end{array}$} & & & \multicolumn{3}{|c|}{$\begin{array}{c}\text { Manometer } \\
\text { Reading mm H2O }\end{array}$} & \multirow{2}{*}{$\begin{array}{c}\mathrm{Q}_{\mathrm{th}} \\
\left(\mathrm{m}^{3} / \mathrm{s}\right)\end{array}$} & & & & & & & \\
\hline & & & & & & & & Left & Right & Net & & & & & & & & \\
\hline 3500 & 0 & 0 & 5 & 10.34 & 0.00048 & 9.93772 & 0.00038685 & 370 & 30 & 340 & 0.0057 & 0.002276 & 0.0027 & 6.8844 & 28 & 320 & 0 & 39.818 \\
\hline 3321 & 1 & 1.96 & 5 & 10.97 & 0.00046 & 9.367 & 0.00036463 & 365 & 30 & 335 & 0.0054 & 0.002259 & 0.0026 & 7.25 & 29 & 332 & 0.6823 & 41.654 \\
\hline 3244 & 2 & 3.92 & 5 & 11.23 & 0.00045 & 9.15013 & 0.00035619 & 360 & 30 & 330 & 0.0053 & 0.002243 & 0.0026 & 7.3662 & 29 & 334 & 1.333 & 42.324 \\
\hline 3221 & 3 & 5.88 & 5 & 11.65 & 0.00043 & 8.82026 & 0.00034335 & 360 & 30 & 330 & 0.0053 & 0.002243 & 0.0026 & 7.6417 & 29 & 337 & 1.9854 & 42.626 \\
\hline 3147 & 4 & 7.84 & 5 & 12.06 & 0.00041 & 8.5204 & 0.00033167 & 360 & 40 & 320 & 0.0051 & 0.002208 & 0.0026 & 7.7899 & 29 & 323 & 2.5863 & 42.962 \\
\hline 2575 & 5 & 9.8 & 5 & 12.94 & 0.00039 & 7.94096 & 0.00030912 & 335 & 55 & 280 & 0.0042 & 0.002066 & 0.0024 & 7.8184 & 29 & 334 & 2.6453 & 49.114 \\
\hline
\end{tabular}

Hasil pengujian menunjukan bahwa effisiensi volumetrik ( $\square$ v) menggunakan bahan bakar azeotropk etanol lebh tinggi dari bahan bakar etanol murni. Hal ini disebabkan kadar air pada azeotrik etanol menyebabkan densitas bahan bakar meningkat, temperatur penguapan juga meningkat. Operasi mesin pada suhu ruangan (temperatur inlet) menyebabkan lebih banyak campuran bahan bakar dan udara yang masuk kedalam ruang bakar. Ikatan hidrogen pada atom $\mathrm{O}$ dan $\mathrm{H}$ pada molekul etanol dan air menyebabkan molekul berkelompok dengan ikatan yang kuat. Dengan demikian pada proses pengkabutan di dalam karburator jarak antar molekul bahan bakar menjadi lebih rapat rapat yang berimplikasi menempati ruangan yang lebih sempit sehingga lebih banyak bahan bakar yang masuk ke ruang bakar. Grafik perbandingan effisiensi antara bahan bakar azeotropik etanol dan etanol murni dapat dilihat pada gambar 2 . 


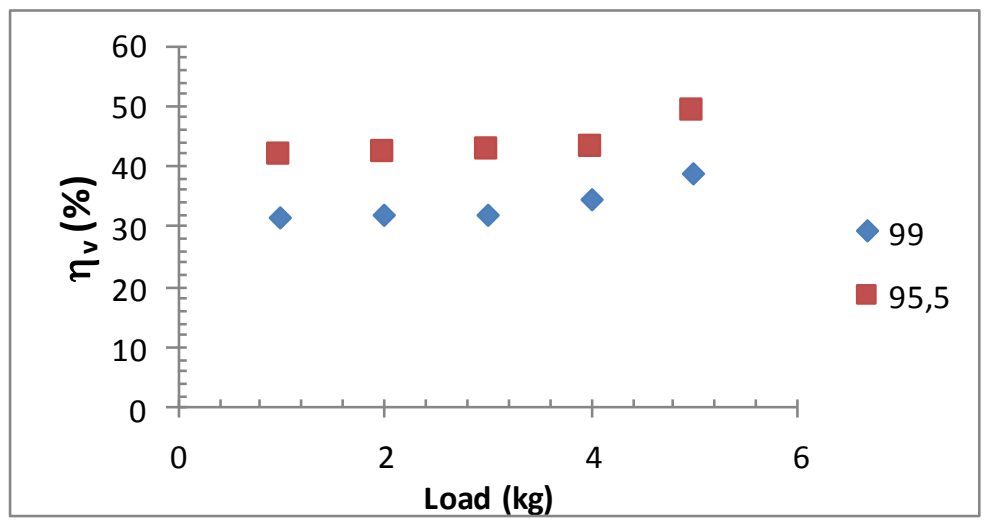

Gambar 2. Perbandingan effisiensi pengisian azeotrik etanol dengan etanol murni

Hasil pegujian terhadap daya mesin menunjukkan daya yang dihasilkan oleh etanol murni lebih rendah dari etanol azeotropik. Walaupun etanol azeotropik mengandung sedikit air yang tidak memiliki nilai kalor sehingga nilai kalor etanol azeotropik lebih rendah dari etanol murni tetapi daya yang dihasilkan etanol azeotropik lebih besar dari etanol murni. Seperti terlihat pada Gambar 3. Hal ini disebabkan lebih banyak bahan bakar yang masuk ke ruang bakar. Dengan lebih banyaknya bahan bakar yang masuk ke ruang bakar berarti kita memasukkan lebih banyak energi sehingga berakibat lebah banyaknya daya yang dihasilkan.

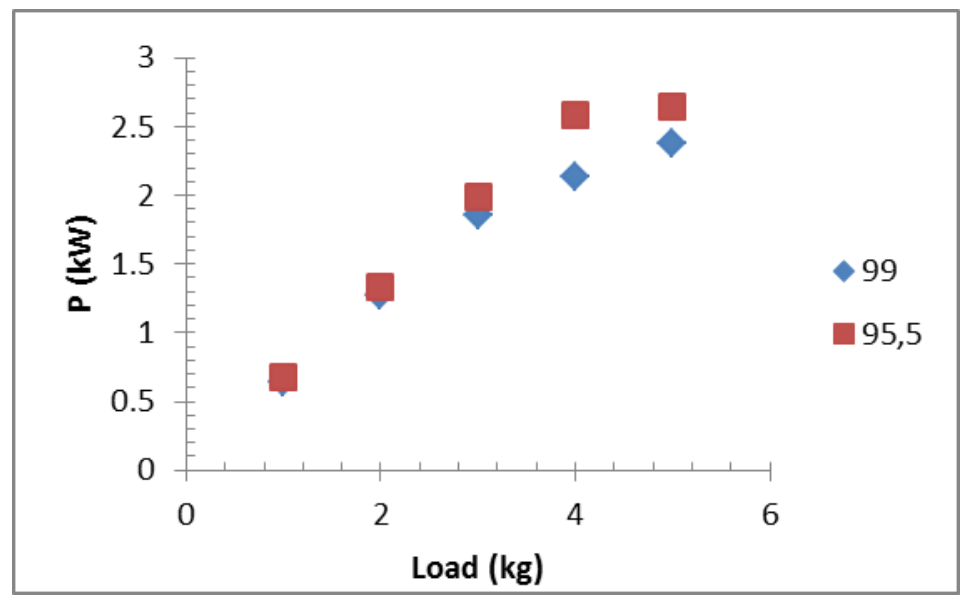

Gambar 3. Perbandingan daya yang dihasilkan oleh bahan bakar azeotik dengan bahan bakar etanol murni

\section{SIMPULAN}

Dengan menggunakan bahan bakar etanol azeotropik dihasilkan daya yang lebih besar dari etanol murni pada beban yang sama. Semakin besar beban perbedaan daya yang dihasikan semakin besar.

Dengan menggunakan bahan bakar azeotropik effisiensi pengisian bahan bakar ke dalam ruang bakar semakin besar. Perbedaan effisiensi tidak dipengruhi oleh beban.

Untuk memperjelas keunggulan dari etanol azeotropik agar dilakukan pengujian terhadap kebutuhan bahan bakar spesifik terhadap etanol azeotropik dibandingkan dengan etanol murni.

\section{DAFTAR PUSTAKA}

[1] Awad, Omar I., Mamat, R., Ali Obed M., Sidik N.A.C., Yusaf, T., Kadirgama K.\& Maurice Kettner. (2018). Alcohol and ether as alternative fuels in spark ignition engine. Renewable and Sustainable Energy Reviews.

[2] Suarta I Made; Baliarta I Nyoman Gede; Rahtika I.P.G. Sopan \& Sunu Putu Wijaya . (2017). The Role of Hydrogen Bonds Of The Azeotropic Hydrous Ethanol Fuel Composition To The Exhaust Emissions. IOP Conf. Series: Journal of Physics: Conf. Series 953

[3] Sathaporn Chuepeng; Sudecha Srisuwan \& Manida Tongroon. (2016) Lean hydrous and anhydrous bioethanol combustion in spark ignition engine at idle. Energy Conversion and Management 128 (2016) 1-11

[4] Suarta I Made; Wardana I. N. G.; Hamidi Nurkholis \& Wijayanti Widya. (2016) The Role of Molecule Clustering by Hydrogen Bond in Hydrous Ethanol on Laminar Burning Velocity. Journal of Combustion. Article ID 5127682, 9 pages. http://dx.doi.org/10.1155/2016/5127682 
[5] Fagundez J.L.S.; Sari R.L.; Mayer F.D.; Martins M.E.S.\& Salau N.P.G. (2016). Determination of optimal wet ethanol composition as a fuel in spark ignition engine. Applied Thermal Engineering

http://dx.doi.org/10.1016/j.applthermaleng.2016. 10.099

[6] Thompson Diórdinis Metzka Lanzanova; Macklini Dalla Nora \& Hua Zhao. (2016) Performance and economic analysis of a direct injection spark ignition engine fueled with wet ethanol. Applied Energy 169 (2016) 230-239

[7] Breaux Baine B.\& Sumanta Acharya. (2013). The effect of elevated water content on swirlstabilized ethanol/air flames. Fuel 105 (2013) 90-102.

[8] Yusri I.M.; Mamat R.; Najafi G.; Razman A.; Awad Omar I.; Azmi W.H.; Ishak W.F.W.\& Shaiful A.I.M. (2017). Alcohol based automotive fuels from first four alcohol family in compression and spark ignition engine: A review on engine performance and exhaust emissions. Renewable and Sustainable Energy Reviews 77 (2017) 169-181
[9] Morganti Kai; Almansour Mohammed; Khan Ahmad; Kalghatgi Gautam \& Przesmitzki Steven. (2018). Leveraging the benefits of ethanol in advanced engine-fuel systems. Energy Conversion and Management 157 (2018) 480497

[10] Schifter I.; Diaz L.; Gómez J.P.\& Gonzalez U.(2013). Combustion characterization in a single cylinder engine with mid-levels hydrated ethanol-gasoline blended fuels. Fuel 103 (2013) 292-298

[11] Suarta I Made; Wardana I. N. G.; Hamidi Nurkholis \& Wijayanti Widya. (2016). The Role of Hydrogen Bonding on Laminar Burning Velocity of Hydrous and Anhydrous Ethanol Fuel with Small Addition of n-Heptane. Journal of Combustion Volume 2016, Article ID 9093428, 8 pages http://dx.doi.org/10.1155/2016/9093428

[12] Munsin R.;Laoonual Y.; Jugjai S.; Imai Y. (2016). An experimental study on performance and emissions of a small SI engine generator set fuelled by hydrous ethanol with high water contents up to 40\%. Fuel 106 (2013) 586-592 